\title{
ANDRAGOGI YANG HUMANIS
}

\author{
Retno Widyaningrum
}

\begin{abstract}
Teaching is principally based on pedagogi and andragogi. Pedagogi is normally used to teach young learners, while andragogi is used for adults. However in practice pedagogi which tends to transfer knowledge and make passive learning is often used for adults. This article discusses how andragogi can be used to make teaching human and how to humanize learners by using andragogi. It is believed that andragogi can create active learning in which the learners can meet their needs such as esteem and selfactualization. Discussing humanistic andragogi from different views this article concludes its importance and advantages in life long learning and provides some suggestion how to carry out humanistic andragogi for active, creative, innovative and joyfull learning.
\end{abstract}

Keywords: pedagogi, andragogi, humanistic andragogi, learning.

\section{PENDAHULUAN}

\section{Latar Belakang Masalah}

Praktik mengajar orang dewasa dilakukan sama saja dengan mengajar anak. Prinsip-prinsip dan asumsi yang berlaku bagi pendidikan anak dianggap dapat diberlakukan bagi kegiatan pendidikan orang dewasa. Hampir semua hal yang diketahui mengenai belajar, ditarik dari penelitian belajar yang terkait dengan anak. Begitu juga mengenai mengajar, ditarik dari pengalaman mengajar anak. Pembelajaran pada anak ditekankan untuk pembentukkan sikap, perilaku emosional, maupun karakter individu. Hal ini berbeda dengan pembelajaran pada orang dewasa yang dianggap sebagai pribadi yang sudah matang, mempunyai kebutuhan dalam menetapkan area belajar untuk mengatasi masalah hidupnya.

Secara umum ada dua metode praksis mengajar yang berlaku yaitu pedagogi dan andragogi. Pedagogi secara umum adalah sains dan seni mengenai cara mengajar di sekolah, sedangkan andragogi secara harfiah dapat diartikan sebagai seni dan pengetahuan mengajar orang dewasa. Andragogi adalah paham yang menempatkan peserta belajar sebagai "orang dewasa". Siswa ditempatkan sebagai subjek dari sistem pendidikan. Siswa sebagai orang dewasa diasumsikan memiliki kemampuan arif merencanakan arah, memilih materi yang bermanfaat, dan mampu menganalisis. Fungsi guru adalah sebagai fasilitator dan bukan menggurui.

Dalam proses pembelajaran, orang dewasa telah melewati banyak fase menuju fase yang lebih kompleks dengan tingkat emosional dan karakteristik yang terbentuk dari masa kecilnya. Oleh karena itu, di dalam membelajarkan orang dewasa, diperlukan guru yang dapat menyeimbangkan karakter-karakter yang telah dimilikinya. Dengan demikian, fungsi pembelajar untuk orang dewasa adalah lebih bersifat sebagai fasilitator dengan memberikan berbagai kemudahan agar orang dewasa itu dapat belajar aktif untuk mencapai tujuan pembelajar. Individu dewasa pada hakikatnya telah mengetahui kompetensinya serta menyadari kebutuhan dan tujuan belajar. Bahkan orang dewasa dapat diajak dan dilibatkan dalam menyiapkan bahan, alat, atau model dalam kegiatan belajar.

Orang dewasa adalah individu mandiri yang dapat mengarahkan diri sendiri maka dalam andragogi yang lebih penting adalah kegiatan belajar dari peserta didik bukan kegiatan mengajar guru. Dalam dunia pendidikan orang dewasa dikenal berbagai aliran filsafat pendidikan yang secara khusus membahas masalah-masalah yang tercakup dalam pendidikan orang dewasa. Secara spesifik filsafat pendidikan orang dewasa membahas tema-tema seperti hakikat pendidikan orang dewasa, kebutuhan, dan minat orang dewasa baik secara konsep maupun relevansi perkembangan orang dewasa itu sendiri, proses pembelajaran, dan peranan pendidikan terhadap perubahan sosial pun turut dibahas.

Satu aliran paling kontemporer pendidikan yang membahas pendidikan orang dewasa adalah aliran humanistik. Aliran filsafat pendidikan humanistik ini terutama berupaya untuk memperkenalkan dan mengembangkan konsep kebebasan dan otonomi sebagai dasar dari perkembangan manusia dalam proses pendidikan orang dewasa. Melalui pendekatan filosofis tersebut, aliran ini berupaya untuk menempatkan manusia sebagai subjek yang memiliki kesadaran diri dan 
berdiri sendiri di dunia yang terus mengalami perkembangan dan perubahan.

Tulisan ini berusaha untuk menilik andragogi dari aliran humanistik. Bagaimana praksis tersebut dapat dilakukan sejalan dengan salah satu aliran yang digunakan sebagai teori belajar?

\section{PEMBAHASAN}

Pedagogi datangnya dari bahasa Yunani "paidagogos" dengan arti: hamba yang menghantar dan mengambil budak-budak pergi balik dari sekolah. Perkataan "paida" merujuk kepada kanak-kanak, yang menjadikan sebab kenapa sebagian orang cenderung membedakan antara pedagogi (mengajar kanak-kanak) dan andarogi.

Kata andragogi berasal dari "andros" artinya orang dewasa, dan "agogus" artinya memimpin. lstilah lain yang kerap kali dipakai sebagai perbandingan adalah pedagogi yang ditarik dan kata "paid" artinya anak dan "agogus" artinya memimpin. Dengan demikian, secara harfiah pedagogi berarti seni dan pengetahuan mengajar anak. Oleh karena itu, menggunakan pedagogi untuk mengajar orang dewasa jelas kurang tepat, karena mengandung makna yang bertentangan.

Pengertian pedagogi adalah menempatkan siswa sebagai individu yang dianggap masih kosong dari ilmu pengetahuan. Ibarat botol kosong, ia perlu diisi dan setelah penuh dianggap lulus/selesai. Konsekuensi metode ini adalah menempatkan peserta didik secara pasif. Murid sepenuhnya menjadi objek dan guru menjadi subjek. Guru mengurui, murid digurui, guru memilihkan apa yang harus dipelajari, murid tunduk pada pilihan tersebut, guru mengevaluasi murid dievaluasi. Kegiatan belajar ini menempatkan guru sebagai inti terpenting sementara murid menjadi bagian pinggiran

Berbalik dari itu, andragogi adalah pendidikan pendekatan orang "dewasa" yang menempatkan individu sebagi subjek dari sistem pendidikan. Knowles (1970) menggambarkan, individu sebagai orang dewasa diasumsikan memiliki kemampuan aktif untuk merencanakan arah, memiliki bahan, menyimpulkan, mampu mengambil manfaat, memikirkan cara terbaik untuk belajar, menganalisis dan meyimpulkan, serta mampu mengambil manfaat dari pendidikan. Fungsi guru adalah sebagai "fasilitator", bukan menggurui. Peranan fasilitator di sini adalah untuk menyadarkan pemelajar tentang keperluan untuk memenuhi rasa ingin tahu, 'need to know'. Oleh karena itu, relasi antara guru dan murid bersifat multicommunication dan seterusnya.

Dalam andragogi yang terpenting dalam proses interaksi belajar adalah kegiatan belajar mandiri yang bertumpu kepada warga belajar itu sendiri dan bukan merupakan kegiatan seorang guru mengajarkan sesuatu (Learner Centered Training/Teaching). Prinsip andragogi seperti yang dikemukakan Knowles (1986) adalah sebagai berikut.

1. Orang dewasa perlu terlibat dalam merancang dan membuat pengukuran semua kerja mereka. Siswa mesti diberikan tujuan sejauh mana pencapaian tujuannya.

2. Pengalaman adalah asas kegiatan pembelajaran. Menjadi tanggung jawab siswa menerima pengalaman sebagai suatu yang bermakna.

3. Siswa lebih berminat mempelajari hal-hal yang berkaitan secara langsung dengan kerja dan kehidupan mereka.

4. Pembelajaran adalah tertumpu pada masalah (problem-centered).

Freire mengatakan bahwa pendidikan haruslah berorientasi pada konsepsi dasar memanusiakan kembali manusia yang telah mengalami dehumanisasi karena sistem dan struktur sosial yang menindas (Freire, 1986). Pernyataan tersebut sejalan dengan pandangan teori belajar humanistik yaitu "memanusiakan manusia". Teori belajar humanistik percaya bahwa belajar merupakan suatu proses di mana peserta didik mengembangkan kemampuan pribadi yang khas dalam bereaksi terhadap lingkungan sekitar. Proses belajar dipandang berhasil jika pemelajar telah memahami lingkungannya dan dirinya sendiri. Teori ini menjelaskan tentang proses belajar yang harus berhulu dan bermuara kepada manusia itu sendiri, menghargai kemampuan pemelajar, dengan kata lain sangat mementingkan keterlibatan aktif peserta didik dalam proses belajar. Dalam praktiknya, aliran humanistik cenderung mendorong manusia untuk berpikir induktif.

Teori ini menjelaskan tentang pengaruh penguatan dari luar diri atau lingkungan seorang siswa, dan aktivitas kognitif dalam diri siswa digabungkan dengan filsafat dasar teori belajar humanistik yaitu "memanusiakan manusia" terhadap kemampuan siswa belajar melalui cara "modelling" atau mencontoh perilaku orang lain. Teori belajar humanistik bersifat elektik yaitu dapat memanfaatkan teknik belajar apapun asal tujuan belajar siswa tercapai. Teori ini yakin bahwa tiap individu pada dasarnya mempunyai kapasitas dan dorongan sendiri untuk mengembangkan potensinya, 
cenderung mendorong manusia berpikir induktif, serta mementingkan faktor pengalaman (keterlibatan aktif siswa) dalam proses belajar.

Para pendukung teori merasa perilaku harus dipahami bukan hanya sekedar dikendalikan atau direkayasa. Mereka percaya bahwa belajar merupakan suatu proses di mana siswa dapat mengembangkan kemampuan pribadi yang khas dalam bereaksi terhadap lingkungan sekitar. Dengan kata lain, siswa tersebut mengembangkan kemampuan terbaik yang ada dalam dirinya. Siswa seharusnya belajar di lingkungan yang menyediakan banyak pilihan sesuai pribadinya sehingga dapat mewujudkan apa yang diinginkannya, serta dapat mengembangkan konsep diri yang sehat, mau menerima keunikan dan perbedaan, serta merasa bahwa dirinya adalah manusia yang layak, berkemampuan, dan berguna.

Secara umum, tujuan pendidikan menurut aliran humanistik adalah untuk mengembangkan pribadi secara utuh. Searah dengan pandangan mereka tentang filsafat manusia, bentuk pribadi itu digambarkan sebagai sosok yang terbuka bagi terjadinya perubahan dan memiliki motivasi untuk belajar secara berkesinambungan, pribadi yang berjuang untuk mencapai aktualisasi diri, dan pribadi yang mampu hidup bersama orang lain.

Tujuan di atas dapat dilihat melalui pandangan dua tokoh utama pendidikan humanistik, Abraham Harold Maslow dan Carl Ransom Rogers, yang mengemukakan bahwa pendidikan berfungsi untuk mengembangkan individu guna mencapai kemampuan aktualisasi diri dan memfungsikan diri secara penuh (Beck, 1992). Dua tokoh ini percaya bahwa manusia tergerak untuk memahami dan menerima dirinya sebisa mungkin. Manusia termotivasi untuk memenuhi kebutuhan-kebutuhan hidupnya. Kebutuhan-kebutuhan tersebut memiliki tingkatan atau hierarki, mulai dari yang paling rendah (bersifat dasar/fisiologis) sampai yang paling tinggi (aktualisasi diri).

1. Physiological needs. Kebutuhan fisiologis adalah kebutuhan akan makan dan minum, pakaian, tempat tinggal, termasuk juga kebutuhan biologis. Disebut sebagai kebutuhan paling dasar karena dibutuhkan oleh semua mahluk hidup, termasuk manusia.

2. Safety/security needs. Kebutuhan akan rasa aman secara fisik dan psikis. Aman secara fisik seperti terhindar dari gangguan kriminalitas, teror, binatang buas, orang lain, dan tempat yang tidak aman. Aman secara psikis misalnya, tidak kena marah, tidak diejek, tidak direndahkan, tidak dimutasikan dengan tidak jelas, dan diturunkan pangkatnya.

3. Social needs. Kebutuhan sosial dibutuhkan manusia agar ia dianggap sebagai warga komunitas sosialnya. Bagi siswa, agar dapat belajar dengan baik, ia harus merasa diterima dengan baik oleh teman-temannya.

4. Esteem needs. Kebutuhan ego termasuk keinginan untuk berprestasi dan memiliki prestise. Seseorang membutuhkan kepercayaan dan tanggung jawab dari orang lain. Dalam pembelajaran dengan memberikan tugas-tugas yang menantang maka siswa akan terpenuhi kebutuhan egonya.

5. Self-actualization needs. Kebutuhan aktualisasi adalah kebutuhan untuk membuktikan dan menunjukkan dirinya kepada orang lain. Pada tahap ini, seseorang mengembangkan semaksimal mungkin potensi yang dimilikinya. Untuk dapat mengaktualisasikan dirinya, siswa perlu suasana dan lingkungan yang kondusif.

Rogers (1986) mengemukakan, individu memiliki kemampuan dalam diri sendiri untuk mengerti diri, menentukan hidup, dan menangani masalah-masalah psikis jika guru membuat kondisi yang dapat mempermudah perkembangan individu untuk aktualisasi diri. Masa lampau memang akan mempengaruhi kepribadian siswa, namun tetap terfokus kepada apa yang terjadi pada sekarang dan bukan masa lalu. Menurut Rogers, motivasi orang sehat adalah aktualisasi diri. Aktualisasi diri adalah proses menjadi diri sendiri serta mengembangkan sifat--sifat dan potensi psikologi yang unik, yang akan berubah sejalan dengan perkembangan hidup. Aktualisasi diri dipengaruhi oleh pengalaman dan masa belajar kanak-kanak.

Rogers dikenal sebagai seorang fenomologis, karena sangat menekankan kepada realitas yang berarti bagi individu. Realitas tiap orang berbeda tergantung kepada pengalamannya. Lapangan pengalaman ini disebut fennomenal field, sedangkan self sebagai fakta dari lapangan fenomenal tersebut. Rogers membagi konsep diri menjadi dua bagian yaitu konsep diri riil dan konsep diri ideal. Untuk mengetahui kedua konsep tersebut sesuai atau tidak maka dikenalkan konsep incongruence dan congruence. Incongruence adalah ketidakcocokan antara self yang dirasakan dalam pengalaman aktual disertai pertentangan dan kekacauan batin. Sedangkan congruence berarti keadaan pengalaman diri diungkapkan dengan seksama dalam konsep diri yang utuh. 
Pribadi yang berfungsi sepenuhnya adalah pribadi yang mengalami penghargaan positif tanpa syarat. Ini berarti, dia dihargai karena nilai adanya diri sendiri sebagai seseorang sehingga tidak bersifat defensif, namun cenderung menerima diri dengan penuh kepercayaan. Schultz (1991) menyebutkan lima sifat khas manusia yang berfungsi sepenuhnya (fully human being) adalah sebagai berikut.

1. Keterbukaan pada pengalaman.

Manusia yang berfungsi sepenuhnya adalah manusia yang menerima semua pengalaman dengan fleksibel sehingga selalu timbul persepsi baru.

2. Kehidupan eksistensial.

Kualitas dari kehidupan eksistensial adalah terbuka terhadap pengalaman sehingga selalu menemukan sesuatu dan selalu berubah menyesuaikan diri sebagai respon atas pengalaman selanjutnya.

3. Kepercayaan terhadap diri sendiri.

Pengalaman akan hidup ketika membuka diri terhadap pengalaman, sehingga akan cenderung bertingkah laku menurut apa yang dianggap benar.

4. Perasaan bebas.

Manusia yang bebas adalah manusia yang memiliki perasaan berkuasa secara pribadi tentang kehidupan dan percaya bahwa masa depan tergantung dengan dirinya sendiri.

5. Kreativitas.

Keterbukaan diri terhadap pengalaman dan kepercayaan kepada diri mereka akan mendorong untuk memiliki kreativitas dengan bertingkah laku secara spontan, tumbuh berkembang sebagai respon dari stimulus yang ada.

Rogers (1986) mengatakan siswa yang belajar hendaknya tidak dipaksa, melainkan dibiarkan belajar bebas. Siswa diharapkan dapat mengambil keputusan sendiri dan berani bertanggung jawab atas keputusankeputusan yang ia ambil. Kebebasan dan tanggung jawab ini diuraikan sebagai berikut.

1. Hasrat untuk belajar, disebabkan adanya hasrat ingin tahu manusia yang terus-menerus terhadap dunia sekelilingnya. Dalam proses mencari jawabnya, seseorang mengalami aktivitas-aktivitas belajar.

2. Belajar bermakna, seseorang yang beraktivitas akan selalu menimbang-nimbang apakah aktivitas tersebut mempunyai makna bagi dirinya. Jika tidak tentu tidak akan dilakukannya.

3. Belajar tanpa hukuman, belajar yang terbebas dari ancaman hukuman mengakibatkan anak bebas melakukan apa saja, mengadakan eksperimentasi hingga menemukan sendiri sesuatu yang baru.
4. Belajar dengan inisiatif sendiri, belajar dengan inisiatif sendiri menyiratkan tingginya motivasi internal yang dimiliki. Siswa yang banyak berinisiatif mampu mengarahkan dirinya sendiri, menentukan pilihannya sendiri, serta berusaha menimbang sendiri hal yang baik bagi dirinya.

5. Belajar dan perubahan, dunia terus berubah, karena itu siswa harus dapat belajar menghadapi kondisi dan situasi yang senantiasa berubah. Dengan demikian, belajar yang sekedar menghafal fakta, menghafal sesuatu dipandang tak cukup.

Howard Gardner (1990) menelaah manusia dari sudut kehidupan mentalnya khususnya aktivitas inteligensia (kecerdasan). Menurut dia, paling tidak manusia memiliki sembilan macam kecerdasan yaitu sebagai berikut.

1. Kecerdasan matematis/logis, yaitu kemampuan penalaran ilmiah, penalaran induktif/deduktif, berhitung/angka, dan pola-pola abstrak.

2. Kecerdasan verbal/bahasa, yaitu kemampuan yang berhubungan dengan kata/bahasa tertulis maupun lisan (sebagian materi pelajaran di sekolah berhubungan dengan kecerdasan ini).

3. Kecerdasan interpersonal, yaitu kemampuan yang berhubungan dengan keterampilan berelasi dengan orang lain, berkomunikasi antarpribadi.

4. Kecerdasan fisik/gerak/badan, yaitu kemampuan mengatur gerakan badan, memahami sesuatu berdasar gerakan.

5. Kecerdasan musikal/ritme, yaitu kemampuan penalaran berdasarkan pola nada atau ritme. Kepekaan akan suatu nada atau ritme.

6. Kecerdasan visual/ruang/spasial, yaitu kemampuan yang mengandalkan penglihatan dan kemampuan membayangkan objek. Kemampuan menciptakan gambaran mental.

7. Kecerdasan intrapersonal, yaitu kemampuan yang berhubungan dengan kesadaran kebatinannya seperti refleksi diri, kesadaran akan hal-hal rohani.

8. Kecerdasan natural, yaitu kemampuan untuk dapat bekerjasama dan menyelaraskan diri dengan alam atau lingkungan. Mereka yang memiliki kecerdasan ini senang pembelajaran di luar ruangan, karyawisata, ramah dan perhatian terhadap kondisi alam.

9. Kecerdasan eksistensial, yaitu kemampuan dalam memahami makna hidup sehingga umumnya seseorang yang cerdas secara spiritual akan memiliki kelebihan yang terlihat dari integritas, karakter dan nilai hidup yang dimilikinya.

Pembelajaran pada manusia sebagai orang dewasa dipertegas lagi oleh Ki Hajar Dewantara, yang merupakan pelopor pendidikan di Indonesia. Ia 
melihat manusia lebih pada sisi kehidupan psikologisnya. Menurutnya manusia memiliki daya jiwa yaitu cipta, karsa, dan karya. Pengembangan manusia seutuhnya menuntut pengembangan semua daya secara seimbang. Pengembangan yang terlalu menitikberatkan pada satu daya saja akan menghasilkan ketidakutuhan perkembangan sebagai manusia. Beliau mengatakan bahwa pendidikan yang menekankan pada aspek intelektual belaka hanya akan menjauhkan peserta didik dari masyarakatnya. Pendidikan dewasa ini hanya menekankan pada pengembangan daya cipta, dan kurang memperhatikan pengembangan olah rasa dan karsa. Jika hal ini berkelanjutan akan menjadikan manusia kurang humanis atau manusiawi. Dari uraian di atas nampak jelas arti penting kemandirian dan kebebasan, yang menegaskan bahwa guru hanyalah sebagai sarana untuk mengembangkan tujuan utama pendidikan yaitu kemampuan individu dalam mengaktualisasikan diri (Maslow, 1977).

Untuk dapat lebih maksimal lagi dalam proses pembelajaran orang dewasa hal-hal yang dirumuskan adalah: (a) siswa dijadikan subjek pendidikan dan pusat proses pembelajaran, (b) teori aktivitas diri dan aktif-positif merupakan dasar dari proses pembelajaran, (c) tujuan pendidikan dirumuskan berkaitan dengan pertumbuhan dan perkembangan siswa daripada tekanan pada penguasaan materi pelajaran, (d) kurikulum sekolah disusun dalam kerangka kegiatan bersama atau kegiatan yang bersifat "proyek", (e) perlunya secara rutin kontrol informal di kelas dan sosialisasi mengajar dan belajar atau kegiatan bersama di tengah-tengah arus deras individualisme, (g) hendaknya banyak diterapkan keaktifan berpikir dan berargumentasi daripada sekedar menghafal atau mengingat-ingat saja, dan (h) pendidikan hendaknya mengembangkan kreativitas siswa. Oleh karena itu, perlulah dipersiapkan pendidik yang fleksibel dalam profesinya. Lebih penting mengajarkan bagaimana belajar daripada apa yang dipelajari.

Perlu dipertimbangkan juga kaitan antara bangunan sekolah, sistem pendidikan, serta guru dan tenaga kependidikan dalam melaksanakan tugas pembelajaran dan pendidikan. Guru harus menuntut dirinya untuk dapat menjadi figur teladan atau model bagi para peserta didik. Sistem kerja dibuat, dari berdasarkan waktu menjadi berdasarkan penampilan mutu kerja. Guru dipersiapkan dan dilatih sehingga mampu berperan seperti di dalam keluarga. Penting bagi guru untuk belajar mendengarkan, ber- komunikasi, dan berelasi dengan seluruh anggota komunitas sekolah. Yang lebih penting lagi guru harus selalu berusaha "memperhitungkan" siswa dan mengkondisikan bahwa siswa itu penting, serta menumbuhkan rasa percaya diri dan harga diri siswa.

\section{KESIMPULAN}

Dalam kerangka pendidikan berpusat pada subjek didik ini, nampak bahwa para penganut pendidikan humanistik menerapkan asumsi-asumsi filosofis kependidikan yang mereka yakini, yaitu kebebasan individual manusia untuk merealisasikan diri, kebertanggungjawaban terhadap aktivitas dan pilihan hidupnya serta hakikat manusia sebagai makhluk yang berkecenderungan baik.

Sebagai penganut paham kebebasan dalam berpikir, kaum humanis melihat bahwa proses belajar dibangkitkan oleh motivasi yang lebih bersifat intrinsik daripada yang bersifat ekstrinsik. Dalam hal ini motivasi bukanlah sesuatu yang secara kaku dibentuk pada diri seseorang oleh orang lain, tetapi lebih sebagai sesuatu yang tercurah dari seorang guru pada subjek didik. Menurut paham humanistik, tujuan pendidikan adalah untuk mengembangkan pribadi manusia yang mampu mencapai aktualitas diri dan pemenuhan diri secara utuh. Dalam mencapai tujuan itu, pendidikan orang dewasa menurut aliran humanistik memberi penekanan pada proses pendidikan yang berpusat pada subjek didik, peran guru sebagai fasilitator dan proses belajar melalui aktivitas penemuan mandiri. Penekanan itu didasari oleh pandangan bahwa orang dewasa sebagai subjek didik memiliki karakteristik tugas perkembangan dan kepribadian pada proses menuju aktualisasi diri dan pemenuhan diri secara utuh.

Dengan demikian, dalam usaha mendidik orang dewasa, menurut kaum humanis, seorang pendidik diharapkan mampu memberi penekanan lebih terhadap adanya patisipasi aktif subjek didik. Melalui sudut pandang semacam ini, guru tidak selalu dianggap sebagai orang yang secara mutlak menguasai atau memiliki otoritas pengetahuan dalam proses alih pengetahuan.

Akhirnya, kita perlu menyadari bahwa tujuan pendidikan adalah memanusiakan manusia. Pendidikan hendaknya menghasilkan pribadi-pribadi yang lebih manusiawi, berguna, dan berpengaruh di masyarakatnya, yang bertanggung jawab atas hidup sendiri dan orang lain, yang berwatak luhur dan berkeahlian. 


\section{DAFTAR PUSTAKA}

Beck, R. C. (1992). Applying psychology, critical and creative thinking. Englewood Cliffs, New Jersey: Prentice Hall.

Freire, P. (1986). Pedagogy of the oppressed. New York: Praeger.

Gardner, H. (1983). Frame of mind: The theory of multiple intellegences. New York: Basic Book.

http://elearn.bpplsp-reg5.go.id/?pilih=news\&aksi=lihat\&id=9

Kartono, K. (1992). Psikologi anak jilid I dan II. Bandung: Mandar Maju.

Knowles, M. S. (1970). The modern practies of adult aduce education, andragogy versus pedagogi. New York: Association Press.

Knowles, M. S. (1977). The modern practice of adult education: From pedagogy to andragogy. New
York: Cambridge; The Adult Education Company.

Knowles, M.S. (1986). The adult learner a neglected species (3rd Edition). Houston: Gulf Publishing Company.

Rogers, C. R. (1986). Freedom to learn (2nd Edition). Merrill Publishing Company.

Schultz, D. (1991). Psikologi pertumbuhan: Model - model kepribadian sehat. Jogjakarta: Kanisius.

Arif, Z. (1994). Andragogi. Bandung: Angkasa.

\section{KETERANGAN PENULIS}

Retno Widyaningrum, S. Kom., M.M., penulis aktif sebagai Dosen di Jurusan Kurikulum Teknologi Pendidikan, Fakultas Ilmu Pendidikan, Universitas Negeri Jakarta mulai tahun 2005 dan Dosen salah satu perguruan tinggi komunikasi di Jakarta. 